\title{
Qatar's Modern Diplomacy and Al-Jazeera's Role in Middle East's Evolutions over the Recent Decades
}

\author{
Ansar Amini (Corresponding author) \\ Department of Politics and International Relations, Islamic Azad University \\ Central Tehran Branch, Tehran, Iran \\ Email: ansar.amini66@yahoo.com \\ Mehdi Akbarsefat \\ Department of Politics and International Relations, Islamic Azad University \\ Central Tehran Branch, Tehran, Iran
}

Received: May 11, 2016 Accepted: May 28, 2016 Published: June 27, 2016

doi:10.5296/jsr.v7i1.9580 URL: http://dx.doi.org/10.5296/jsr.v7i1.9580

\begin{abstract}
Development of information technology and internet today has given the concept of diplomacy a meaning broader than the past. Modern diplomacy is a mixture which has gained a specific position among academic topics. It is worth noting that the modern diplomacy was resulted from the world's changes after the World War II, where governments could no longer be the only players in the international system. The concept of modern diplomacy makes sense in relatively different ways; general diplomacy, real-time diplomacy, Nich diplomacy, etc. But our main focus in the paper is placed on the Jazeera's role in Middle East's evolutions over the recent decades. As a grand manifestation of modern diplomacy in the Middle East during the past decades, Al Jazeera is sometimes considered to be Qatar's foreign policy benchmarks (index), as it has had an effective role in events related to the country's diplomacy from the time it was established. We assume Qatar's political bargaining power in the international system, especially in the Persian Gulf region, as having enhanced over the recent years. In the present paper, therefore, the authors are about to address questions as to how Qatar's modern diplomacy has made it an active country in the Persian Gulf and in the Middle East region as well, and to what extent Al Jazeera's role is deemed to be serious in the recent changes happened in the Middle east. The present research's assumption emphasizes the role of establishment of Al Jazeera Media Channel as a diplomacy-enabling tool after changes were made in Qatar's government structure, a role which obviously affects the Middle East's recent evolutions (Movements and revolutions in Arabian Countries).
\end{abstract}


Analytic-descriptive approach has been used in the present paper.

Keywords: Diplomacy, Modern Diplomacy, Foreign Policy

\section{Introduction}

Definitions and concepts are changed with world's evolutions. The Twentieth century witnessed a lot of changes, ranging from the First and Second Wars and formation of two-pole system to happening of the Cold War. In the meantime, there was also a revolution in the field of communications and technology which resulted in advent of computer and development of several types of media networks. In its evolution trend, the Twenties century also witnessed the appearance of new players in the field of politics. In the classic knowledge of international relations, traditional realism in particular, governments were counted as the only players in the international system, while specialization of international affairs together with an understanding of the point that governments cannot play a role in all affairs caused some other players to become meaningful. In fact, with expansion of evolutions in the international system, governments came to recognize themselves as inefficient in some affairs. So, they had to transfer some of their responsibilities in functional areas to non-governmental players such as private corporations and organizations. During this process, the government-based traditional diplomacy had to undergo some changes as government was no longer the only decision-maker in the international system.

As representatives of people, groups had founded some organizations, and multi-national corporations were internalized within the international system. In such a new system, everything was happened behind the glass, in the light of globalization and technological revolution, and secrecy and negotiations conducted by government representatives away from public's eyes were going to be replaced by another function. Modern diplomacy came to be meaningful in the light of globalization of media's and non-governmental players' power. In the new global system, referred to as Post-Westphalia, people were counted as audience of international scene and followers of governments' acts through communication networks. So affecting their thoughts takes priority in order to be keeping with countries' interests and national purposes. This is where attention is drawn towards media's role in meeting these purposes. Modern diplomacy has several kinds. Among these is general diplomacy, a type of diplomacy that is definitely of most importance. This is a tool which is learned by some countries to have its own strong effectiveness.

In the present paper, we use modern and general diplomacies in the same meaning, with the purpose of utilizing media's tool power, especially Al Jazeera's, in Qatari government's activism. Qatar, a very small country among Persian Gulf states, has far been identified as following an active recognized diplomatic policy including general and media diplomacies. Under the title of diplomatic mediation, it dispatches various messages to near and far countries of its own geographic area. The country has intended to play a regional role as one of the major players of the region. During the recent crises in the region, Qatar has made efforts to adopt an active policy. Qatar's active policy is described by acting as a support for 


\section{Macrothink}

Libyan rebels against Gaddafi, trying to be a mediate between Yemeni rebels and Ali Abdollah Saleh's regime, as well as opposing Asad's regime in Syria and supporting Sheikh Yusuf al-Qaradawi, a pro-Muslim Brotherhood cleric who is opposing the Zionist regime on the one hand, and making friendly relationship with neighboring countries in Persian Gulf and close relations with Iran on the other.

Although overthrow of Muslim Brotherhood regime in Egypt as well as the relative peace governing regional countries such as Syria indicate Qatar's policies as not being that much successful, but it should be analyzed considering the country's geographic area, the new identity growth developed from the time Hamad Bin Khalifa Al Thani's ascending to the throne, and the history of only two decades in length. What is important is the country's planning for taking major regional roles. Qatar has truly found that being a regional power in the future requires not ignoring the region's affairs and events happened in it. With its performance, the country has changed the concepts of the field of international relations and political science in connection with regional and global powers although it is deprived of such hardware power advantages as population, area, land, mineral resources, etc. Meanwhile, Qatar's focus has been placed on soft power and modern diplomacy since the arrival of Hamad Bin Khalifa Al Thani.

This paper assumes that Qatar has managed to introduce itself using two indications over the recent years; the first is taking advantage of modern diplomacy with emphasis on general diplomacy managed by Al Jazeera network, and the second is making use of Niche Diplomacy, which is the same in meaning as Branding and in parallel with the general diplomacy. Al Jazeera has been considered as an important factor for making an image of Qatar in the region' and world's public opinions, introducing the country as an advocate of peace and active mediation in the recent years. This is understandable for Qatar's policies especially when being informed that Al Jazeera first established its English-language section in 2006. It caused the country to ascend from a regional level to a trans-regional one, making it able to use general diplomacy in order to be connected to international and trans-regional areas.

\section{Literature Review}

In the recent years, there have been increasingly several papers written on modern diplomacy and its associated concepts such as general diplomacy. The paper "Functions of modern diplomacy in the field of international relations: mutual influentiveness and influence-ability" may be one of the first papers written concerning modern diplomacy in Iran in the $80^{\text {th }}$ solar decade, which describe the definition of modern diplomacy. Dr. Simber considers the World War I as the origin of change in definition of diplomacy. He believes that it was after Paris Peace Conference that diplomats found themselves as being faced with a changed world, with concepts which had been specialized such as international economy, arms control, and the like. Meanwhile, development of information technology had made the circumstances ready to change the diplomacy definition again. Negotiations between foreign affairs ministries' diplomats, as governments' representatives, were no longer able to be conducted behind closed doors and away from public's eyes, as growth of media, telephone, television, and the 
internet and its programs afterwards had made diplomacy enter a public scene. Thus, general diplomacy was given a global meaning as a modern tool for managing public's mental path. This is what caused the private nature of diplomatic relations to undergo a generalization process by the media. The author believes that the definition of diplomacy has been changed with any evolution of the international structure.

According to Dr. Simbor, happening of the World Wars and the Cold War afterwards, as well as technological revolution are considered as changes in the international structure. Given the mentioned changes, governments' role in international relations faded away, and non-governmental organizations came to be effective players of modern diplomacy in this structure. The author calls this point "de-governmentalization". Simber states that when used correctly by government, modern diplomacy can act as the guarantor of global peace and overcome ideological wars. He considers diplomats and overall governments as able to help each other form an efficient government. This attribute is given importance with development of communications and transfer of information in modern diplomacy (Simber, 2006, pp. 171-194). A series of international-level papers and books have been written concerning the importance of modern diplomacy in trend of Qatar's foreign policy.

A conference entitled "General diplomacy, global policy-making in the $21^{\text {st }}$ century" was also held in Qatar in the spring of 2014, with the purpose of introducing students' findings in James A. Baker III Institute for Public Policy at Rice University, in partnership with Hamad Bin Khalifa University and Qatar Institute. The former is cooperating with the other countries in the field of development and expansion of Qatar's communications and technology. Lasted for 5 days in Doha, the conference had discussions based on combating threats and bioterrorism, addressing a humanitarian response to Syria's conflicts, improving the low-rate social-economic health in the US, Qatar, etc. Holding such conferences implies Qatar's attention towards the importance of modern diplomacy. But in Iran, unfortunately, it is discussed only from a journalistic viewpoint, and there are no remarkable research evidences for the influence of Al Jazeera and modern diplomacy approach on Qatar's activism in the international system. Among the other papers written in the international field is the one written by Tal Samuel-Azran and entitled Al Jazeera, Qatar, and new tactic in state media diplomacy".

It discusses the history of modern diplomacy especially general diplomacy, classifying it in terms of chronological order from the beginning to the end of the Cold War, and from the Dissolution of the Soviet Union to the present. It also clarifies that to what extent this type of diplomacy, as an efficient tool, has been influencing interests and foreign policy of the international system's major players. After noting this, the author discusses the second cycle of re-development of general diplomacy, which was improved in the late 1980s and early 1990s. This is when Al Jazeera network burgeons. Azran further discusses the conflicts between Qatar and Saudi Arabia and that what influences Al Jazeera has had in solving those conflicts. He believes that the role of Al Jazeera has become so much highlighted that Arabia finds it, in some affairs, as a threat against itself. This is why it has even, in some cases, unsuccessfully tried to make a media link between Qatar and Saudi Arabia. 


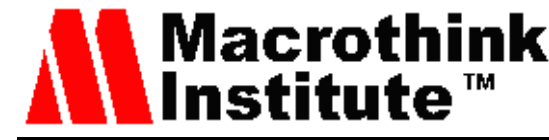

The paper emphasizes the assumption that with such a public/private media diplomacy, Qatar is trying to play a more active role in the region. Saudi Arabia, as a country with a historic background, is also in fear of this matter because Qatar has not agreed with Saudi Arabia on several issues including uprisings and transfer of powers in the Middle East. Even, it has acted in the opposite direction while responding to some conflicts like the transfer of power in Egypt and Syria. Azran concludes the paper with the analysis that with the help of media and communication networks, the new diplomacy coming in the new era can change the world's classic communications towards a hybrid and electronic one. For this purpose, governments are required to pay more attention to this type of diplomacy in order to gain further interests (Arzan, 2013).

\section{Diplomacy and its Types}

Diplomacy has several types whose conceptual variety has been increase over the recent decades. Although its range covers politic diplomacy all the way through to economic diplomacy, etc., the traditional definition of diplomacy is still "Countries representatives' art of negotiating with each other. From this point of view, diplomacy is more given an international meaning or international relations behavior, which is respected by various countries in different ways (Barston, 2006, p. 1). In fact, it can be noted that diplomacy is a key to one of the roles of the international system, the formation of relation between independent countries, which was displayed more seriously after the Westphalia Peace Treaty. Then, relations between governments were principally transformed into a new form where countries, regardless of their differences, interacted and communicated with each other (Lee \&Hocking, 2011). In such a meaning, diplomacy is established so as to make countries interact with each other, with the purpose of peace-loving. Thus, it can be noted that diplomacy is the ability to solve international conflicts through goal-oriented negotiations and meetings.

In its traditional meaning, diplomacy recognizes diplomats, who are governments' representatives, as activists for solving international conflicts and defending countries' national interests. After experiencing two world-wide World Wars, people were linked to politics. This change in public's attitude did reveal itself for governments the necessity of paying attention to their vote and opinion while making governmental decisions. It was in such circumstances that traditional diplomacy was replaced by modern diplomacy. Due to the poor relations between countries in traditional diplomacy, most part of diplomatic negotiations was conducted over expansionist wars and protection of borders, and generally bilateral relations. From the second half of the twentieth century, trend of world's change expanded the definition of diplomacy.

Governments' sovereignty became weaker than the past and the trend were going towards the way in which governments would not be the only players of the new international system. "With the development of nuclear weapons and Cold War from 1950 and international terrorism from 1970 on, governments' strategic interdependence strategy widely spread over the world" (Lee \& Hocking, 2011). Traditional communications no longer met the needs of this strategy. Globalization came to be meaningful. Based on this event, range of 
communications was considered more seriously than the past. So, governments decided to make use of the power of media. This was because the new world needed a new diplomacy. The old methods were going to be disappeared, and the world changed, "a world which had been developing fast by the combination of new values and technologies, new geopolitical relations, new lifestyles and communications, and it was not possible to put this modern world in old and historic cultural nests" (Aminiet al., 2013, pp. 47-53). So, traditional diplomacy was replaced by the newly-generated modern diplomacy where media had a vital role and governments were not the only international activists. What comes to mind from the modern diplomacy and its appearance is the peremptory connection with advancement in technology. The communication aspect became wider compared to the past. In parallel with introduction of modern diplomacy, terms such as virtual diplomacy, instant diplomacy and real-time diplomacy are being used. In the meantime, general and virtual diplomacies are counted as two interesting aspects of interaction between diplomacy and information and communication technology (Simbor\&Ghorbani, 2009, pp. 43-61). In fact, media's intervention, through which ordinary people involve in international affairs, led to a phenomenon called general diplomacy, which was of much importance in conflicts. Inauguration of BBC England in 1920, that is, after the World War I, and establishment of VOA channel in February of 1942, the midst of World War II, where it acted for Germany' and Allies' advertisements and psychic health, may be two classic examples of general diplomacy in the twentieth century (Taylor, 2007).

Today, general diplomacy is part of political theoretic topics, with emphasis on effect of governments' purposeful thoughts on people. "General diplomacy refers to programs supported by government and aiming at informing or influencing public thoughts in other countries; its major tools are release of text, motion pictures, cultural exchanges, radio and television \{and the Internet\} (Sabolan Ardestani, 2004). Some researchers have defined virtual diplomacy by using general diplomacy, and counted use of media including newspaper, internet and its programs such as Twitter, Facebook, YouTube, as general diplomacy tools (Horton, 2010, p. 13). Anyhow, application of general diplomacy in theoretic topics has increasingly grown. Today, countries try their best to present a proper image of themselves, as public beliefs are considered more important than the past. Media and education are, therefore, efficient tools in general diplomacy.

The extraordinary influencing strength, which enables media to build a positive or negative image of a country's social values, makes the government administration interests equal to media's performance as well as to the purposes planned in this diplomacy. So, the government would need to build a strong media administration, with professional and expanded communications and empowered internet in order to display its interest as being in parallel with the people (audience and viewers) (Ahadi, 2013, pp. 105-128). One of the purposes general diplomacy is about to meet is cultural exchanges, that is, "Forcing and target countries and directing their actions towards purposes of conductors of this diplomacy" (Darvish, 2005). In this way, countries like Qatar have been active in enabling their media tools, so that some believe that "today, influence of television channels on international policy is not considered as an exclusively western phenomenon only. Over the past years, 
information proliferation has happened, and western channels have lost their monopoly on international information and news coverage. Today, networks such as Al Jazeera are counted as serious rivals for CNN and BBC (Simbor\&Ghorbani, 2009). Today, Al Jazeera is a network which has been received a global dimension, and introduced Qatar as a peace-keeping and mediator country.

\section{Qatar and Transfer of Power}

In 1995, Emir of Qatar was overthrown through a coup planned by his son, Sheikh Hamad and supported by Saudi Arabia and United Arab Emirate (Reuter News Service, 1995). Meanwhile, according to some authors, Saudi Arabia had taken a twofold policy. It declared itself as supporting Hamad Bin Khalifa Al Thani, on the one hand, and was an advocate of the overthrown Sheikh Khalifa, on the other, causing the relations between Qatar and Saudi Arabia to be undermined (Karava, 2009, pp 401-420). However, after coming to power, Hamad Bin Khalifa planned fundamental changes in his work program trying to liberalize his country and establishing democracy bases in it. He was about to eradicate Qatar's dependence on the neighboring countries and Persian Gulf Cooperation Council and, thus, tried to empower the economy of his country. Next, he launched city council election (Rathmell, 2000, pp 47-62), while the country was recognized as a small country which was outside regional power issues.

Located on the southern coast of Persian Gulf, Emirate of Qatar has a population of almost 1.8 million, $83 \%$ of which are living in Doha, the capital of the country, until the end of 2012, according to the ministry of foreign affairs' statistic. The country's economy is based on oil and gas. Despite its small geographic area, Qatar is seeking to introduce itself as an important player in the international scene and parade against strong neighboring countries such as Saudi Arabia and Iran as well as emerging powers like Turkey, with opportunities and abilities in hand. Qatar's role in the region is displayed in several ways. Qatar's policy is supported by the capital gained from oil and gas as well as from the Al Jazeera network" (Nemati, 2013). After Hamad Bin Khalifa Al Thani ascended to the throne, Qatar came to think of branding and, according to Gareth Evans, the former foreign minister of Australia, used Niche diplomacy, a diplomacy used by countries to parade as well as to do special political works (Evans \&Grant, 1991). This type of diplomacy is adopted by small countries which try to develop their general diplomacy profile by means of image-building (media- and advertising-types) of themselves with a certain reason. So, they are seeking a way to enlarge their image throughout the global civil society (Rockower, 2008). Even some of large countries are using this type of diplomacy to show off their reputation in international relations. Relevant examples include Swiss Bank's branding in the world, French's culture, New York's strategy to buying.

Using Niche diplomacy and its active foreign policy in the recent years, Qatar has managed to introduce itself as a mediator able to solve the region's conflicts. Among the actions Qatar has taken in the recent years (after revolutions in some regions of Africa and Middle East in 2011) is intervening in Yemen through Persian Gulf Cooperation Council, which caused Ali Abdullah Saleh, the country's ousted president, to be given a judicial immunity. Intervention 
in Egypt, supporting Muslim Brotherhood group (care should be taken to Qatar's pragmatism-brotherhood policy for exploiting brothers' social capital), financial supports in Libya, and contribution to NATO's attack on Libya all indicate the country's effort to develop the range of its relations in the international system as well as an understanding of change made in its structure. Al Jazeera has been considered as Qatar's main tool to gain the political-religious mediation brand. "The country has had a successful trend being able to apply highlight Qatar's general diplomacy tool to highlight the country's role in world's map in order to find a place among European countries, the US, and Arab world" (Grando, 2014).

\section{Al Jazeera}

In the second half of 1990s, an Arabian ousted journalist recommended Emir of Qatar to establish a 24-hour professional channel. It was followed by Hamad Bin Khalifa's consent, making the Al Jazeera channel to be born (Cherkaoui, 2014). It was only after a short time that the channel expanded taking into account professional criteria of global news agencies. It introduced tolerance of opinions as its government's symbol, with the government's slogan "opposite thought and opinion". This changed, itself, world countries' mentality towards Arabian countries especially Qatar (Seib, 2005, p 601-615), insofar as some authors have mentioned Qatar as a gateway to the Arab world. The network is one of the most important communication organizers in today's world (Gilboa, 2007). With its own general diplomacy, Qatar has presented to what extent and how much strong a small country can be acting despite of its too small size.

It comes to be important when some researchers believe that Al Jazeera, with purposeful activism, has provided an open political atmosphere where opposite groups are able to express their opposition to the government showing some countries of the region antagonism towards human rights and political and financial corruptions (national/domestic) (Saker, 2002), what Arabian newspapers such as the Saudi newspaper Al-Arabiya had not been able to do in their countries beforehand. Thus, Al Jazeera created an open media atmosphere drawing people' and intellectuals' attention to events happened in the Middle East and the Arab world. Qatar's performance in the field of informal diplomacy has made Doha a successful model of general diplomacy in the region. Among Qatar's successful general diplomacies over the past years are use of branding pattern (such as giving an undivided attention to Qatar airways), taking advantage of media diplomacy, becoming well-known as a successful regional mediator, and activating religious diplomacy. In fact, Arab nations' uprising in the beginning of 2011 provided Qatari politicians with an opportunity to adopt an active foreign policy against Arab revolutions by taking advantage of their political-religious record and relying on Al Jazeera network's media power (Rezakhah, 2011).

\section{Al Jazeera and Playing a Role in the Region's Trend of Events}

According to a number of authors, "Qatar has been one of the successful countries to be able to make use of general diplomacy in advancing their foreign policy" (Grando, 2014).Advocacy of pan-Arabism seems to be one of AL Jazeera's purposes, as in early years after its establishment, it played a vital role in battles between Israel and Palestine in Masjid al-Haram. In September 28, 2000, Israeli military forces launched an attack on Masjid 
al-Haram and seized it. Meanwhile, English-language networks like BBC lesser covered this event than Al Jazeera which displayed vast scenes of Palestinians breaking the seizure and taking Al-Aqsa Mosque back. This caused the reputation of the channel to become globally well-known placing it alongside the large global networks, as English-language networks did not pay any attention to Gaza attack (Amin, 2004).

Photographing and filming killed and injured people, Al Jazeera communicated its news to the whole world, which motivated Arab countries all over the world, from Morocco to Oman, to demonstrate against Israel. Broadcasting a Palestinian young (Muhammad al-Durrah) who was shot in this war, the channel called for supporting Arabians' solidarity for pan-Arabism as well as Arabian countries' follow up to the media campaign it had already launched (Anderson, 1991). Following its expansion, Al Jazeera responded to trans-regional events. After September 11 attacks, the channel introduced Bin Laden, al-Qaeda's leader, as being an opposed voice. This caused Omar al-Issawi, one of the channel staff, to say that "we are opposed not to broadcast Bin Laden's voice, as we know if we do not do it, some others will do" (al-Issawi, 2003). After this event, Qatar invited several experts with different viewpoints to analyze the al-Qaeda's actions and to make them respond to Al-Qaeda's claims. At the same time, it broadcasted the US's aerial bombardment over Afghanistan and disseminated Bin Laden's tapes, which effectively help the channel become well-known in explicitly responding to global events.

During the US's attack on Iraq in 2003, Al Jazeera broadened its news coverage and declared its opposition by broadcasting war events from all around Iraq. This was in contradiction to Saudi Arabia's behavior in this regard. Some experts consider this Qatari channel's ability as thankful to the state of its location as its news-broadcasting office had been located in Iraq three weeks before beginning of the war (March 3, 2003) (Rockower, 2008). This trend seems to be in conflict with Saudi Arabia Al-Arabia channel's policy, as Al-Arabia had problem with Al Jazeera's coverage type. Al-Arabia was a prudent network and advocate of English-language network's dialogue. But, Al Jazeera had gone for beyond this position (Hammond, 2007), and wanted a broader setting to gain an international place which could also introduce the small country of Qatar as a player for mediating in Middle East's conflict. It is worth mentioning that with its mediating role in the recent ten years, Qatar has managed to gather the parties to the region's conflict around a table in Doha. In such conflicts as between Yemen and Houthis during 2007-2008, Qatar hosted the negotiations to put an end to battles in Lebanon, facilitate negotiations between Sudan government and opposing movements in Darfur, etc. (Dickinson, 2012).

Following the highlighting of the role of the channel in public mouths and the region's government, Al Jazeera began broadcasting its program in English language as of 2006. The point which should be emphasized is Al Jazeera's role while Saudi Arabia was coming close to (approaching) this country in 2007. Qatar's mediation in Lebanon, Yemen, and other involved countries of the region caused regional threats against Iran to be eliminated, and reduced the costs of Iran's battle with the region's hostile groups. With respect to its competitive history to Iran, Saudi Arabia could not accept this matter, so it made Saudi Arabia think about making relation with Qatar. So, a session was held between Hamad Al 
Thani's representative and Saudi Arabians, on the pretext of cooperating to prevent development of terrorism in the region (Khatib, 2013, pp. 417-431). It is worth noting that $\mathrm{Al}$ Jazeera network's president was present in this session (Samuel, 2013, p. 1311). It was after this session that Al Jazeera was accused, by well-known news agencies such as WikiLeaks and New York Times, of political transaction between Qatar and Saudi Arabia (Samuel, 2013, 1295).

Anyhow, the cooperation continued to the point that Saudi Arabia hosted Qatar in June 2008 and an agreement on "political, safety, trade, economic, advertising, and cultural enhancement as well as media cooperation" was made between the two countries (Al Qassaemi, 2011). It was, of course, after a while that the cooperation was transformed into an enmity. Following the tensions in Tunis beginning as of September 18, 2010, people of the countries of the region and overall, the whole Middle East's people, who were all Arabians, demonstrated and began opposing their governments. Tunis, Egypt, Yemen, and Libya were countries which witnessed the first sparks of revolution ignited. After these countries, Bahraini rebels demonstrated on the streets. Wadah Khanfar, the former president of $\mathrm{Al}$ Jazeera, describes the role of the channel in Arabian Spring as follows:

In 2011, Al Jazeera removed the hidden curtain against the eyes of millions of viewers all around the world, and was broadcasting squares' events (around which opponents of governments had gathered) from Sidi Bouzid to Jisr Al-Shughur. These revolutions were continuously covered and we were reporting youths' combat to reach their munificence, gain freedom, and get free from the oppression and dictatorship (Black, 2011).

This news coverage again increased Qatar's credibility among Arab countries as well as in the entire world. This should be analyzed considering the continuation of Al Jazeera's approach, as Qatar had become a voice for opponents of Hosni Mubarak's government in Egypt in 2011. The network even founded a new channel named Al Jazeera Mubasher Misr which was lively reporting Egypt's evolutions. This new channel conducted a series of interviews with leaders of opposition parties and groups who generally emphasized the role of Muslim Brotherhood (Al Qassemi, 2012). It seems that this guiding could not be irrelevant to the process of supporting selection of Morsiso as to lead the Muslim Brotherhood's movement considered by Qatar. Interestingly, Saudi Arabia along with the United Arab Emirate, on the other hand, supported those military forces protecting Mubarak. It also spent millions of dollar to suppress the region's revolutions and the countries' military and economic costs, a policy which was exactly opposed to Qatar's attitude towards the region's movements" (Lippman, 2013). So, there were two different attitudes towards the regions' event; the first is for Saudi Arabia which acted against rebels' and opposition's uprising, empowered weakened governments, and was highly in conflict with Muslim Brotherhood. Its main effort was made not to permit the Muslim Brotherhood group to come to power in the revolutionary countries especially in Egypt. The other side, Qatar, was supporting in full opponents and Muslim Brotherhood through its media tool, Al Jazeera, and broadcasting revolution's images throughout the world.

As well, Al Jazeera extended its news coverage across Libya, and broadcasted the video of 
people demonstrating against Muammar Gaddafi. It also exaggerated the phrase "Martyrs" as written on opponents' banners. Qatar also intervened in raising the three-color flag of Libya's opponents instead of Gaddafi regime's green flag.

Although Qatar's intervention was reproached by a group of Libya government's opponents, these oppositions were further reflected by Steven Stawlf, a Time magazine journalist who had conducted interviews with the Transitional Council (Sotloff, 2012). Keeping its trend, Al Jazeera repeated its own scenario in Syria where it employed journalists who concurred in a way with Muslim Brotherhood's thoughts. Among them was Ahmad Al-Abda, the brother of Anas Bin Al-Abdawho was a member of Syrian National Council. He was also counted as a theorist of Muslim Brotherhood (Mahdi, 2012). According to a number of authors, Al Jazeera's effort to change the government in Syria, as well as the reports communicated by Ibrahim Hilaland exaggerations made about Syria's status were all of a biased tone (Mahdi, 2012). Media experts believe media to be able to accelerate evolutions trend by highlighting news and events, as well as to show facts as in parallel with a certain group's interests. This can be observed for the Qatari Al Jazeera channel in particular. In covering Syria's evolutions, Al Jazeera adopted exaggeration and replication advertising approaches and acted through notion-making against Syria's regime which had a worthy position among Arab nations due to its anti-Zionism positioning and support for resistance.

Meanwhile, criticized for exaggerating Syria's unrest and, inversely, censoring Bahrain news from the beginning of Syria's evolutions, Al Jazeera announced the Syrian security forces' shooting demonstrators in several cities, and declared Syrian cities' demonstration as being the largest public protests among those already held (Shahrood, 2011). But regardless of those views considering Al Jazeera's performance as a kind of propaganda, it can be noted that this agency has strangely linked with Qatari regime's policy having an impressive impact on the implementation of the country's strategies, insofar as some experts believe that the country, with the help of Al Jazeera, has managed to damage Saudi Arabia's power in the region (Cherkaoui, 2014). This matter comes to be more important when we consider the small geographic area of this country compared to that of the other powers of the region and of the Middle East and compare Qatar's government's experience with the diplomacy history of large countries like Iran. Qatar is a small country, so if independence from England is considered as a basis for a country to act as a regional player, its diplomacy history would be less than fifty years. This further reveals the power of use of modern diplomacy and media.

\section{Conclusion}

The modern diplomacy emerged in several forms in the era of change or twenties century, and expanded simultaneous with the end of the Cold War, in order to come to compete more seriously with the traditional diplomacy. It is known to have several kinds including general, digital, and media diplomacies. All categories of this kind of diplomacy pay specific attention to public thoughts instead of relying only on the government's or its charged' affaires. Nevertheless, they are not heedless of government. The basis for our analysis in the present paper was Qatar's modern diplomacy in the field of foreign policy as well as the country's use of Al Jazeera network in connection with the roles it has played in the region over the two 
recent decades. The age of Al Jazeera network is less than two decades. It was established by the former Emir of Qatar, Hamad Bin Khalifa Al Thani, who came to the throne through a coup against his father in 1995. In fact, growth and development of Qatar's playing role in the recent years is thankful to his revisionist-asking policies. Due to the small area and weak military power, Qatar is not able to intervene in regional issues directly. So, it has always tried to take a mediating diplomacy by using Al Jazeera's news broadcasting. This small country has, therefore, followed a specific strategy in the region and among Arab countries by adopting a modern diplomacy.

Among the actions Qatar has taken in the recent years (after the revolutions in some regions of Africa and the Middle East in 2011)is Qatar's intervention in Yemen through Persian Gulf Cooperation Council, which caused Ali Abdullah Saleh, the country's ousted president, to be given a judicial immunity. Intervention in Egypt, supporting Muslim Brotherhood group, financial supports in Libya, and contribution to NATO's attack on Libya all indicate the country's effort to develop the range of its relations in the international system as well as an understanding of change made in its structure. This approach, along with Al Jazeera's accompaniment to clarification of the region, has made Qatar able to introduce itself as an effective mediator, that is, to make a specific brand for the country. Comparing the geographic capacity of this newly-established country, it comes to be not that much important whether Qatar has been successful or not keeping to this path. What we were about to emphasize in the present paper is AL Jazeera network's bold role in Qatar's diplomacy as well as the fact that with its news coverage during the Middle East's recent events, the network has become able to display the power of modern diplomacy and introduce itself as an active player in presence of regional powers like Iran, Saudi Arabia, and Turkey.

\section{References}

Simbor, R.,\&Ghorbani, A. (2009). Modern diplomacy in foreign relations: Approaches and change tools. International Quarterlyon Foreign Relations, 4(1), 43-61.

Simbor, R. (2006). Modern diplomacy functions in international relations: Mutual influentiveness and influenceability. Foreign Relations Quarterly, 1, 20-33.

SabilanArdestani, H. (2004). Operationalizing psychic operation, psychic operation quarterly, (5).

Darvish, R. (2005). The U.S. book (6):General diplomacy in the US. Tehran: The Cultural Institute for International Studies and Research.

Amini, A., Shafieie, SH., and Najmi, M. H. (2013). Non-developed countries: Third wave and position of NAM development process. WorldRural Observation, 5(3), 1-5.

Ahadi, A. (2013). Public diplomacy in the Middle East: A comparative analysis of the U.S. 


\section{Ml Macrothink}

Journal of Sociological Research

ISSN 1948-5468

2016, Vol. 7, No. 1

and Iran.Iranian Review of Foreign Affairs, 4(1), 105-128.

Amin, H.Y. (2004). Social engineering: Transnational broadcasting and its impact on peace in the Middle East. Global MediaJournal, 4(3). Available at:

http://lass.purduecal.edu/cca/gmj/sp04/gmj-sp04-amin.htm (accessed 1 January.

Anderson, B. (1991) Imagined communities: Reflections on the origin and spread of nationalism. London: Verso.

Al-Issawi, O., \&Pattiz, N. (2003). Al Jazeera, radio Sawa founders report on media in the Middle East. Available at: http://web.international.ucla.edu/asia/article/.

Al Qassemi, S.S. (2012) Morsi's win is Al Jazeera's loss. Available

at:http://www.al-monitor.com/pulse/originals/2012/almonitor/morsys-win-is-al-jazeeras-loss. html.

Al Qassemi, S.S. (2011). How Saudi Arabia and Qatar became friends again. Available at: http://www.foreignpolicy.com/articles/2011/07/21/how_saudi_arabia_and_qatar_became_fri ends_again .

Black, I. (2011). Al-Jazeera boss WadahKhanfar steps down to be replaced by Qatari royal.

The Guardian. Available at: http://www.theguardian.com/media/2011/sep/20/al-

jazeera-wadah-khanfar-replaced (accessed: 20 February 2014)

Gareth, E.,\& Grant, G. (1991). Australia's foreign relations in the world of the 1990.

Melbourne: MelbourneUniversity Press.

Lee, D.,\& Hocking, B. (2011).International encyclopedia of political science.Sage:

Bertrand Bardie.

Dickinson, E. (2012). Qatar builds a brand as mediator. Christian Science Monitor. Available

at:http://www.csmonitor.com/World/Middle-East/2012/0328/Qatar-builds-a-brand-as-mediato r.

Eytan, G., \& Powers, S. (2007). Public diplomacy of Al-Jazeera. In P. Seib (Ed.), New media and the new Middle East. New York: Palgrave.

Granado,G. (2014). Strong small state diplomacy: A case study of how Qatar used power

Well. Available at https://www.academia.edu

Hammond, A. (2007). Saudi Arabia's media empire: Keeping the masses at home. Arab 
Media\& Society. Available at: http://www.arabmediasociety.com/?article.

Karava, M. (2009). Royal factionalism and political liberalization in Qatar. The Middle East Journal, 63(3), 401-420.

Khatib, L. (2013). Qatar foreign policy: The limits of pragmatism. International Affairs, $89(2), 417-431$.

Lippman, T. (2013). Support for el-Sisi: What's in it for Al-Saud? Available at: http://www.mei.edu/content/support-el-sisiwhat's-it-al-saud (accessed 20 February 2014)

Mahdi, E. (2012). Al Jazeera in Syria: A case of tunnel vision. Al Akhbar, 28 March.

Available at: http://english.alakhbar.com/content/al-jazeera-syria-case-tunnel-vision. Barston, R. P. (2006).Modern diplomacy. London: Pearson Education.

Reuter News Service (1995). Prince deposes Father in Qatar Palace coup. Available at: http://www.deseretnews.com/article/425035/PRINCE-DEPOSES-FATHER-IN-QATAR-PALA CE-COUP.html.

Rockower, P.(2012). Qatar's public diplomacy. December 12, 2008. Accessed July 18, available at http://mysite.verizon.net/SJRockower/PSR/QatarPDv4.pdf

Rathmell, A., \&Schulze, K. (2000). Political reform in the gulf: The case of Qatar. Middle Eastern Studies, 36(4), 47-62.

Seib, P. (2005). Hegemonic no more: Western media, the rise of Al-Jazeera, and the influence of diverse voices. InternationalStudies Review, 7, 601-615.

Saker, N. (2002). Satellite realms: Transnational television, globalization and the Middle East. London: I.B. Tauris.

Samuel-Azran, T. (2013). Al-Jazeera, Qatar, and new tactics in state-sponsored media diplomacy. American BehavioralScientist, 57(9), 1293-1311.

Sotloff, S. (2012). Why Libyans have fallen out of love with Qatar. TIME.com. Available at: http://content.time.com/time/world/article/.

Horton, T. (2010). New technology and public diplomacy. Public Diplomacy Magazine, summer, $p 13$.

Taylor, P. (2007). Munitions of the mind: A brief history of military psychological 


\section{Macrothink \\ Journal of Sociological Research \\ ISSN 1948-5468 \\ 2016, Vol. 7, No. 1}

operations. Place Branding and Public Diplomacy, 3(3), 196-204.

TarekCherkaoui, Qatar Museums (2014). Al Jazeera's changing editorial perspectives and the Saudi-Qatari relationship, polecom.org/)

Tal Samuel-Azran(2013). Al-Jazeera, Qatar, and new tactics in State-Sponsored media diplomacy. American BehavioralScientist September, 57(9), 1293-1311.

\section{Copyright Disclaimer}

Copyright for this article is retained by the author(s), with first publication rights granted to the journal.

This is an open-access article distributed under the terms and conditions of the Creative Commons Attribution license (http://creativecommons.org/licenses/by/3.0/). 